\title{
Spore formation in Actinomadura dassonvillei (Brocq-Rousseu) Lechevalier and Lechevalier
}

\author{
By S. T. WILLIAMS, G. P. SHARPLES AND \\ R. M. BRADSHAW \\ Department of Botany, University of Liverpool, Liverpool L69 $3 B X$
}

(Received 5 June 1974)

The genus Actinomadura (Lechevalier \& Lechevalier, 1970a) contains aerobic actinomycetes with a branching substrate mycelium which sometimes gives rise to aerial myceliumbearing chains of arthrospores. The walls contain meso-diaminopimelic acid but usually lack arabinose and galactose, the pattern designated as type III by Becker, Lechevalier \& Lechevalier (1965). In some strains, traces of L-diaminopimelic acid and arabinose are present (Mordarska, Mordarski \& Goodfellow, 1972). Lechevalier \& Lechevalier (1970 a) transferred Nocardia madurae (Gordon, I966), N.pelletieri (Gordon, 1966) and N. dassonvillei (Gordon \& Horan, 1968) to the genus Actinomadura. Several new species have since been described (Nonomura \& Ohara, I97I).

Actinomadura dassonvillei differs from $A$. madurae and $A$. pelletieri in several ways. While the substrate hyphae of the latter species are generally stable, those of $A$.dassonville $i$ fragment in a manner very similar to hyphae of Nocardia species (Lechevalier \& Lechevalier, I970 a; Guzeva, Agre \& Sokolov, I972). Its macroscopic appearance and some physiological characters are similar to those of Streptomyces griseus (Gordon \& Horan, 1968). On most media it forms abundant aerial hyphae with chains of spores, unlike many strains of $A$. madurae and $A$. pelletieri which form little aerial growth and lack spores. Whole cell hydrolysates of $A$. madurae and $A$. pelletieri contain the sugar madurose, but this is absent from $A$. dassonvillei (Lechevalier \& Lechevalier, I970 $a, b$ ). In a numerical taxonomic study of nocardioform organisms, Goodfellow (197I) found that $A$. dassonvillei strains formed a minor cluster, separate from other Actinomadura species and all other clusters.

In the present study, the process of spore formation by the aerial hyphae was studied by electron microscopy. It was hoped to obtain further information on the characteristics and relationships of this species.

\section{METHODS}

Actinomadura dassonvillei strains NCTCIO488 and NCTCIO489 were studied. They were grown on oatmeal agar at $25^{\circ} \mathrm{C}$ for 7 to $\mathrm{I} 4$ days.

Material for preparation of ultra-thin sections was obtained by growing the organisms on a sheet of cellophane overlying the medium. Growth was scraped off and fixed in buffered $\mathrm{I} \%(\mathrm{w} / \mathrm{v})$ osmium tetroxide for $\mathrm{I} 6 \mathrm{~h}$ at room temperature. It was then washed with $0.5 \%$ (w/v) uranyl acetate for $3 \mathrm{~h}$. Specimens were dehydrated with ethanol, embedded in an epoxy resin (Spurr, 1969), sectioned, and stained with uranyl acetate and lead citrate.

Carbon replicas of spores were prepared using growth on coverslips inserted into the medium at an angle of about $45^{\circ}$. Coverslips with growth on them were removed from the medium, air-dried and coated with carbon under vacuum. Small squares $(2 \times 2 \mathrm{~mm})$ were cut 
from the carbon film and floated off in distilled water. After digestion overnight in $5 \mathrm{~N}-$ sodium hydroxide, they were washed six times with distilled water and picked up on Formvar-coated grids, They were shadowed with gold-palladium before examination. The replicas and sections were examined with an EM 6B electron microscope (A.E.I.) operated at $60 \mathrm{kV}$.

Scanning electron microscopy was carried out with agar blocks $(5 \times 5 \times 5 \mathrm{~mm})$ cut from the colonies. These were quenched in isopentane at about $-150^{\circ} \mathrm{C}$ and freeze-dried in an Edwards-Pearse tissue dryer for $18 \mathrm{~h}$. They were coated with gold-palladium under vaccum and examined with a Stereoscan electron microscope (Cambridge Scientific Instruments) operated at $20 \mathrm{kV}$.

\section{RESULTS AND DISCUSSION}

Both strains of $A$. dassonvillei produced abundant aerial hyphae and spore chains. Examination by scanning electron microscopy showed that chains were long, with up to about 50 spores. In mature cultures most of the chains were straight, but in younger cultures they were often twisted. Examination at higher magnification showed that this was due to the zig-zag arrangement of developing spores in these chains (Fig. I $a$ ). Not all chains in any one culture had this arrangement, which seemed to occur at an intermediate stage in spore formation.

Carbon replication of spores showed that they were covered by a sheath with a distinct pattern (Fig. I $b$ ). This closely resembled the patterns observed in Streptomyces griseus and other Streptomyces species, which reflect the fibrillar nature of the sheath (Wildermuth, Wehrli \& Horne, 197I; Wildermuth, 1972a, $b$; Williams, Bradshaw, Costerton \& Forge, 1972).

Spore formation was initiated by a single ingrowth of the hyphal wall (Fig. I $c$ ) to produce a cross-wall of the kind designated type I by Williams, Sharples \& Bradshaw (1973). The narrow electron-dense mid-line of the ingrowth persisted throughout spore delimitation. The order of formation of cross-walls in a chain was irregular. The first elements delimited were often long (up to $2 \mu \mathrm{m}$ ) and were sometimes subdivided by further cross-wall formation (Fig. I c). The completed cross-walls increased considerably in thickness, reaching 200 to $250 \mathrm{~nm}$. At the same time the lateral walls of the spores increased in thickness to 30 to $60 \mathrm{~nm}$ (Fig. I $e$ ). These developments occurred within the prominent sheath. Spores of various lengths were finally delimited by cleavage of the thickened end-walls along their electrondense mid-line (Fig. I $d$ ). At this stage, disruption of the sheath between the spores was apparent. From these observations it seems likely that the zig-zag arrangement of developing spores chains was caused by lateral displacement of spores within the sheath as their adjoining end-walls thickened. Young spores contained nuclear material, membranous elements and polyphosphate granules (Fig. I $c$ ). As their walls thickened, cytoplasmic contents were less easily discerned and many electron-light areas were present (Fig. I $d, e$ ).

Spore production by $A$. dassonvillei is therefore by fragmentation of a hypha within its sheath, a process common to many actinomycetes (Williams et al. 1973). While spores in chains may be delimited almost simultaneously (as in Streptomyces) or basipetally (as in Micropolyspora rectivirgula), in $A$. dassonvillei the cross-walls form in a relatively uncoordinated manner and result in spores of various lengths. In this respect, the spore formation process in $A$. dassonvillei resembles the fragmentation of Nocardia substrate hyphae into irregularly sized units and indeed the fragmentation of its own substrate hyphae. The zig-zag form of the sporulating hyphae has also been compared with that of Nocardia substrate hyphae before fragmentation (Lechevalier \& Lechevalier, 1970a). Hewever, our results 

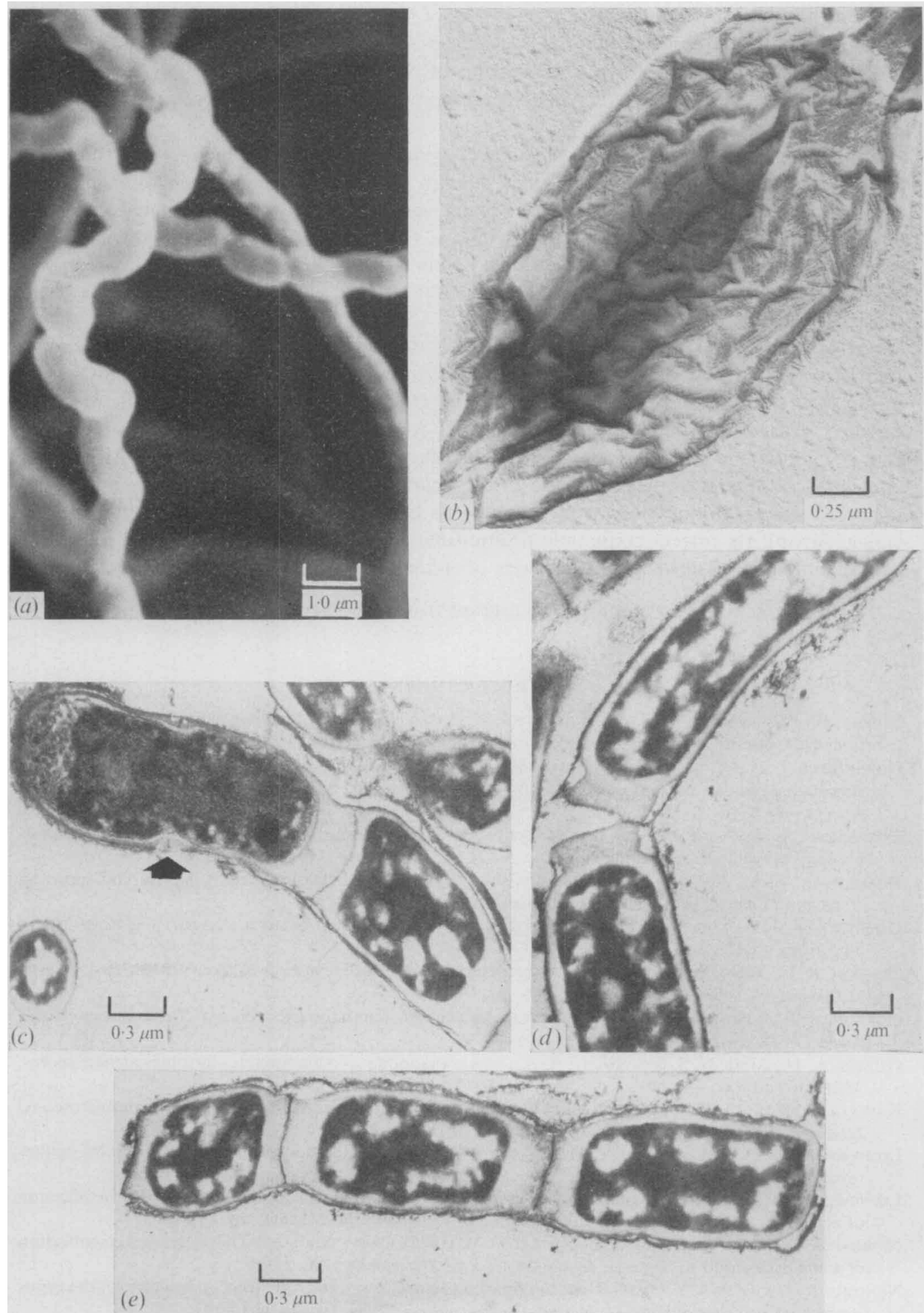

Fig. 1. (a) Spore chains showing variation in arrangement of spores (scanning electron micrograph). (b) Carbon replica of spore showing fibrillar pattern on sheath. (c) Initiation of cross-wall (arrowed) to subdivide long element. Note electron-dense polyphosphate granule. $(d)$ Cleavage of thickened end walls and sheath disruption. (e) Part of spore chain with thickened end walls and lateral walls, with prominent sheath. 
suggest that this may be a superficial resemblance. The fibrillar pattern of the sheath, which resembles that in streptomycetes, also occurs on sporing aerial hyphae of Nocardia asteroides (Bradshaw, unpublished). The presence of polyphosphate granules in $A$. dassonvillei is another characteristic shared with Nocardia species (Kawata \& Inoue, I965; Williams et al. 1973).

The most prominent feature of $A$. dassonville $i$ spores was the development of very thickened end-walls and somewhat less thickened lateral walls. Very similar developments were observed in Micropolyspora retivirgula, where spore walls reached a diameter of $100 \mathrm{~nm}$ (Dorokhova, Agre, Kalakoutskii \& Krassilnikov, 1969, 1970). The spores were formed within a prominent sheath and, when mature, varied in size and shape. Streptomyces megasporus also produces spores with very thickened end walls and moderately thickened lateral walls (Dorokhova, Agre \& Krassilnikov, I971).

Actinomadura dassonvillei therefore shares a number of morphological characteristics with species of Nocardia, Micropolyspora and Streptomyces. It is difficult to place this species in any one genus using morphological criteria. Other evidence is also contradictory. The absence of arabinose, galactose and lipid LCN-A from its cell hydrolysates distinguish it from Nocardia and Micropolyspora species (Lechevalier \& Lechevalier, 1970 $b$; Mordarska et al. 1972). It differs from $A$. madurae and $A$. pelletieri in many morphological and physiological characters (Goodfellow, 197I), and in its lack of madurose (Lechevalier \& Lechevalier, $1970 b$ ). Its correct taxonomic position may best be found by determination of its overall similarity to all recognized species of Actinomadura, Micropolyspora and Nocardia.

This investigation was supported by a grant from the Science Research Council.

\section{REFERENCES}

BeCKer, B., Lechevalier, M. P. \& Lechevalier, H. A. (1965). Chemical composition of cell-wall preparations from strains of various form-genera of aerobic actinomycetes. Applied Microbiology 13, 236-243.

Dorokhova, L. A., Agre, N. S., Kalakoutskit, L. V. \& Krassilnikov, N. A. (1969). Fine structure of sporulating hyphae and spores in a thermophilic actinomycete, Micropolyspora rectivirgula. Journal de Microscopie 8, 845-854.

Dorokhova, L. A., Agre, N. S., Kalakoutskit, L. V. \& Krassilnikov, N. A. (1970). A study of the morphology of two cultures belonging to the genus Micropolyspora. Mikrobiologiya 39, 79-86.

Dorokhova, L. A., AGRe, N. S. \& Krassilnikov, N. A. (1971). Ultrastructure of hyphae and spores in Actinomyces megasporus. Mikrobiologiya 40, 450-455.

Goodfellow, M. (197I). Numerical taxonomy of some nocardioform bacteria. Journal of General Microbiology 69, 33-80.

GoRDON, R. E. (1966). Some criteria for the recognition of Nocardia madurae (Vincent) Blanchard. Journal of General Microbiology 45, 355-364.

Gordon, R. E. \& Horan, A. C. (1968). Nocardia dassonvillei, a macroscopic replica of Streptomyces griseus. Journal of General Microbiology 50, 223-233.

GuZEVA, L. N., AGRE, N. S. \& Soxolov, A. A. (1972). Taxonomy of actinomycetes forming catenate spores. Mikrobiologiya 4I, 957-96I.

KAWATA, T. \& INOUE, T. (1965). Ultrastructure of Nocardia asteroides as revealed by electron microscopy. Japanese Journal of Microbiology 9, IOI-I I4.

LeCheVAlier, H. A. \& LecheVAlier, M. P. (1970a). A critical evaluation of the genera of aerobic actinomycetes. In The Actinomycetales, pp. 393-405. Edited by H. Prauser. Jena: Gustav Fischer.

LeCheVAlier, M. P. \& LeChevalier, H. A. (I970 $b$ ). Chemical composition as a criterion in the classification of aerobic actinomycetes. International Journal of Systematic Bacteriology 20, 435-444.

MordarsKa, H., Mordarski, M. \& Goodfellow, M. (1972). Chemotaxonomic characters and classification of some nocardioform bacteria. Journal of General Microbiology 71, 77-86.

NoNOMURA, H. \& OHARA, Y. (I97I). Distribution of actinomycetes in soil. XI .Some new species of the genus Actinomadura Lechevalier et al. Journal of Fermentation Technology 49, 904-912. 
SPURR, A. R. (1969). A low-viscosity epoxy resin embedding medium for electron microscopy. Journal of Ultrastructural Research 26, 31-43.

WILDERMUTH, H. (1972a). The surface structure of spores and aerial hyphae in Streptomyces viridochromogenes. Archiv für Mikrobiologie 81, 309-320.

WILDERMUTH, H. (1972b). Morphological surface characteristics of Streptomyces glaucescens and Streptomyces acrimycini, two streptomycetes with 'hairy' spores. Archiv für Mikrobiologie 81, 321-332.

Wildermuth, H., Wehrli, E. \& HoRNe, R. W. (I97I). The surface structure of spores and aerial mycelium in Streptomyces coelicolor. Journal of Ultrastructural Research 35, 168-180.

Williams, S. T., Bradshaw, R. M., Costerton, J. W. \& Forge, A. (1972). Fine structure of the spore sheath of some Streptomyces species. Journal of General Microbiology 72, 249-258.

Williams, S. T., Sharples, G. P. \& Bradshaw, R. M. (1973). The fine structure of the Actinomycetales. In Actinomycetales: Characteristics and Practical Importance, pp. I I3-130. Edited by G. Sykes and F. A. Skinner. London and New York: Academic Press. 